ISSN 2075-163X

www.mdpi.com/journal/minerals

Article

\title{
Comparing Health Risks to Load-Haul-Dump Vehicle Operators Exposed to Whole-Body Vibration Using EU Directive 2002/44EC, ISO 2631-1 and ISO 2631-5
}

Tammy R. Eger ${ }^{1}{ }^{*}$, Aaron M. Kociolek ${ }^{2}$ and James P. Dickey ${ }^{3}$

1 School of Human Kinetics, Laurentian University, Sudbury, Ontario P3E 2C6, Canada

2 Department of Kinesiology, McMaster University, Hamilton, Ontario L8S 4L8, Canada;

E-Mail: kociolam@mcmaster.ca

3 School of Kinesiology, Western University, London, Ontario N6A 5B8, Canada;

E-Mail: jdickey@uwo.ca

* Author to whom correspondence should be addressed; E-Mail: teger@laurentian.ca;

Tel.: +1-705-675-1151 ext. 1005; Fax: +1-705-675-4845.

Received: 12 December 2012; in revised form: 8 January 2013 / Accepted: 8 January 2013 /

Published: 14 January 2013

\begin{abstract}
The purpose of this study was to evaluate health risks to operators of large and small load-haul-dump (LHD) vehicles exposed to whole-body vibration (WBV), based on criteria established in ISO 2631-1, ISO 2631-5, and EU Directive 2002/44 EC. Studies simultaneously evaluating health risks based on all three standards are limited. Operator WBV exposure was measured in accordance with ISO 2631-1 using a tri-axial seat pad accelerometer. According to ISO 2631-1, four of the seven large LHD vehicle operators and three of six small LHD vehicle operators were exposed to WBV above the 8-hour vibration dose value (VDV) health guidance caution zone (HGCZ). According to the EU Directive 2002/44/EC criteria one of the seven large LHD vehicle operators and one of the six small LHD vehicle operators were exposed to WBV above the VDV daily exposure limit. However, health risks predicted by ISO 2631-5 criteria only placed one of seven large LHD vehicle operators and one of the six small LHD vehicle operators in the high probability of an adverse health effect category. Thus, the probability of adverse health effects, associated with WBV exposure during LHD vehicle operation, is suggested to be greatest based on the ISO 2631-1 8-hour VDV HGCZ and lowest based on ISO 2631-5 $\mathrm{S}_{\text {ed }}$ criterion values.
\end{abstract}


Keywords: whole-body vibration; ISO 2631-1; ISO 2631-5; EU Directive 2002/44/EC; load-haul-dump vehicle; mobile equipment

\section{Introduction}

It is estimated that $4 \%$ to $7 \%$ of the labor force in Canada, the United States and European countries are exposed to whole-body vibration (WBV) that increases their risk of harmful health effects [1]. Changes in mining work practices and a demand for increased productivity has seen almost all heavy physical work in mining replaced with sedentary work and mechanized equipment operation [2], the latter resulting in increased exposure to WBV. Operators of load-haul-dump (LHD) vehicles, in particular may be at increased injury risk due to postural demands and WBV exposure levels associated with harmful effects to the human body [3-5].

Although the human body dampens most vibration frequencies transmitted through the operator-seat interface, WBV between $1 \mathrm{~Hz}$ and $20 \mathrm{~Hz}$ results in resonance of the spinal column, pelvis, internal organs and soft tissues [6,7]. Health effects associated with short term WBV include muscle fatigue, discomfort, distorted motor performance, headache, loss of balance, motion sickness, increased heart rate, hyperventilation, decreased cognitive functions, as well as, diminished speech and vision [8]. An even greater concern arises from chronic health effects associated with regular exposure to WBV, which include: spinal degeneration, spinal disc disease, disc failure, sciatic pain, herniated discs, low back pain, and gastrointestinal disorders [1,7-9].

Previous research has demonstrated that WBV exposure can cause mechanical overloading of the spine [1]. Subsequently, spinal degeneration occurs from increased internal forces where mechanical damage to the anatomical structure of the vertebrae is present [10]. Furthermore, the magnitude of internal forces is also affected by muscular activity in response to WBV, whereby muscles alternate cycles of increased and decreased activity, which also increases the risk of spinal instability when muscles are in a relaxed phase [10]. This behavior is further exaggerated when awkward bending postures are sustained, whereby activity of multifidus muscles (spinal stabilizing muscle) is decreased [11]. In particular, operators of LHD vehicles frequently sustain awkward driving postures to maximize driver sight lines [12], which increase their risk of musculoskeletal injury.

Measuring and assessing WBV of a seated mobile equipment driver, at the operator-seat interface, is most frequently accomplished with the International Organization of Standards report (ISO 2631-1) [13]. Aside from clearly describing methods for quantifying WBV, the ISO 2631-1 standard also presents guidelines for safe exposure limits to $\mathrm{WBV}$ in relation to human health, comfort, perception and motion sickness [13]. In accordance with ISO 2631-1 guidelines, WBV exposure is evaluated with the frequency weighted root-mean-square (r.m.s.) acceleration method when crest factors (CFs) are less than nine [13]. However, this standard also presents an alternative method of analysis, the fourth power vibration dose value (VDV), which is suggested when CFs are greater than nine [13]. Under this circumstance, the fourth power VDV is a superior indicator of WBV exposure since it is more sensitive to multiple shocks [14]. When considering the 8-hour frequency-weighted r.m.s. acceleration value A(8), the ISO 2631-1 report defines the upper and lower limits of the 8-hour health guidance 
caution zone (HGCZ) as $0.45 \mathrm{~m} / \mathrm{s}^{2}$ and $0.90 \mathrm{~m} / \mathrm{s}^{2}$ respectively [13]. Similarly, when considering the VDV, the upper and lower limits are $8.5 \mathrm{~m} / \mathrm{s}^{1.75}$ and $17 \mathrm{~m} / \mathrm{s}^{1.75}$ respectively [13].

Another method for the evaluation of negative health effects associated with WBV exposure is outlined in the European Union Directive 2002/44/EC. The A(8) daily exposure limit value and daily exposure action values established in the European Union Directive 2002/44/EC are $0.5 \mathrm{~m} / \mathrm{s}^{2}$ and $1.15 \mathrm{~m} / \mathrm{s}^{2}$ respectively while the VDV daily exposure action value and daily exposure limit value are $9.1 \mathrm{~m} / \mathrm{s}^{1.75}$ and $21 \mathrm{~m} / \mathrm{s}^{1.75}$ respectively.

Despite the improved predicting power of the VDV in relation to human health, comfort, perception and motion sickness, recent research concluded that existing standards did not adequately describe human response to WBV when multiple shocks are present [14]. Furthermore, it was argued that the ISO 2631-1 standard failed to identify upper and lower exposure limits and associated risk of injury based on the VDV [14]. The United States Army Aeromedical Research Laboratory developed the Health Hazard Assessment (HHA) method, which they used to predict the risk of lumbar spinal injury to Tactical Ground Vehicle operators exposed to WBV with multiple shocks [14].

Early success for evaluating the risk of adverse health effects from WBV containing multiple shocks with the HHA method was used to establish ISO 2631-5 [15]. Health predictions using this assessment method are based on the biomechanical response of the lumbar spine to WBV; this contrasts with the VDV approach, which is based solely on the mathematical properties of the vibration signal [15]. The ISO 2631-5 standard utilizes biodynamic models to predict spinal acceleration, regression models to predict peak L4/L5 compressive stress, and cumulative models to assess repeated shock and injury probability [16]. Furthermore, two separate biodynamic models are utilized including a single degree-of-freedom model to predict the L4/L5 response to shocks in the X and Y-axes, and a recurrent neural network model that predicts L4/L5 response to shocks in the Z-axis only [16].

These aforementioned models are used to calculate predictors of adverse health effects including the daily equivalent static compressive dose $\left(S_{e d}\right)$, as well as, the cumulative risk factor $(R)$. Over the course of a typical working day, a $S_{\text {ed }}$ value less than $0.5 \mathrm{MPa}$ indicates low probability of an adverse health effect, whereas a $S_{\text {ed }}$ value greater than $0.8 \mathrm{MPa}$ indicates high probability of an adverse health effect at lifetime exposure $[15,16]$. Similarly, over an average career, an R-value less than 0.8 indicates low probability of adverse health effect, whereas an $\mathrm{R}$ value greater than 1.2 indicates high probability of an adverse health effect $[15,16]$.

While research suggests that LHD vehicle operators exposed to regular WBV are more likely to suffer from adverse health effects based on ISO 2631-1 guidelines, limited research has documented health risks predicted by the ISO 2631-5 standard [4,5] or the newer EU Directive 2002/44/EC exposure guidelines. Reports of musculoskeletal discomfort associated with measured vibration exposures are also limited. Consequently, the primary objectives of this study are to (1) determine the body area associated with musculoskeletal discomfort during the operation of large and small LHD vehicles, (2) determine if there is a difference in probability of adverse health effects according to ISO 2631-1 and EU Directive 2002/44/EC when frequency weighted r.m.s. acceleration values are considered, (3) to determine if there is a difference in probability of adverse health effects from impulsive vibration when VDVs (ISO 2631-1; EU Directive 2002/44/EC) are compared to relative risk predicted by the $S_{\text {ed }}$ and $\mathrm{R}$ factor values (ISO 2631-5); and (4) to determine if the probability of adverse health effects are different for small and large LHD vehicle operators. 


\section{Results}

\subsection{Drivers' Questionnaire Findings}

Every participating LHD operator indicated they had work-related pain/discomfort in at least one body region (Table 1). Nine of the 13 mobile equipment operators reported pain/discomfort in the neck making this the body region associated with the greatest pain. Eight operators reported pain/discomfort in the lower-back and six reported discomfort in the upper-back. The greatest severity of pain was reported in the neck/head for one small LHD operator and in the low back, and both arms for one large LHD operator.

Table 1. LHD (load-haul-dump vehicle) operator characteristics along with self reported activity levels and work-related musculoskeletal pain/discomfort. Areas of severe and very severe pain/discomfort are bolded.

\begin{tabular}{|c|c|c|c|c|c|c|c|c|c|c|c|c|}
\hline \multirow[b]{2}{*}{$\begin{array}{c}\text { Size } \\
\text { Category }\end{array}$} & \multirow[b]{2}{*}{$\begin{array}{c}\text { LHD } \\
\text { Vehicle }\end{array}$} & \multicolumn{4}{|c|}{ Driver Information } & \multirow{2}{*}{\multicolumn{7}{|c|}{$\begin{array}{l}\text { Self Reported Musculoskeletal Pain/Discomfort } \\
\text { Severity by Body Region* } \\
\text { (1 = mild; } 2 \text { = moderate; } 3 \text { = severe; } 4 \text { = very severe })\end{array}$}} \\
\hline & & $\begin{array}{c}\text { Age } \\
\text { (year) }\end{array}$ & $\begin{array}{c}\text { Height } \\
\text { (m) }\end{array}$ & $\begin{array}{c}\text { Mass } \\
(\mathbf{k g})\end{array}$ & $\begin{array}{c}\text { Driving } \\
\text { Exp. }\end{array}$ & & & & & & & \\
\hline Large & & & & & & $\mathrm{H} / \mathrm{N}$ & UB & LB & R-Arm & L-Arm & R-Leg & L-Leg \\
\hline LHD & 1 & \multicolumn{4}{|c|}{ personal information not provided } & & & & 2 & 2 & 3 & 3 \\
\hline Vehicles & 2 & 51 & 1.72 & 75 & 20 & 2 & & 4 & 4 & 4 & 2 & 2 \\
\hline (haulage & 3 & 43 & 1.83 & 85 & 15 & 2 & 2 & 2 & 1 & 1 & 3 & 2 \\
\hline capacity & 4 & 53 & 1.83 & 82 & 25 & 1 & & 2 & & & & \\
\hline greater & 5 & 50 & 1.73 & 84 & 20 & 3 & 1 & 2 & 3 & & & 1 \\
\hline than 6 & 6 & 64 & 1.79 & 116 & 44 & 2 & & & 1 & & & \\
\hline yards) & 7 & 42 & 1.83 & 95 & 20 & & 1 & 2 & & & & \\
\hline Small & 8 & 49 & 1.83 & 103 & 15 & 4 & 2 & & & 2 & & 2 \\
\hline LHD & 9 & 44 & 1.91 & 110 & 8 & & & & 1 & & & \\
\hline Vehicles & 10 & 22 & 1.71 & 82 & 1 & 2 & 1 & 1 & 1 & 1 & 1 & 2 \\
\hline (haulage & 11 & 49 & 1.83 & 103 & 15 & & 1 & 2 & & & & \\
\hline $\begin{array}{l}\text { capacity } \\
\text { less than }\end{array}$ & 12 & 44 & 1.83 & 79 & 20 & 2 & & & 2 & 2 & & \\
\hline $\begin{array}{l}\text { or equal } \\
\text { to } 6 \text { yards }\end{array}$ & 13 & 57 & 1.7 & 75 & 20 & 1 & & 1 & & & & \\
\hline
\end{tabular}

Note: $* \mathrm{H} / \mathrm{N}=$ head/neck; UB = upper back; LB = lower back; $\mathrm{R}-$ Arm $=$ right shoulder, right elbow and/or right wrist/hand; L-Arm = left shoulder, left elbow, and/or left wrist/hand; R-Leg = right thigh, right knee, and/or right foot; L-leg = left thigh, left knee, and/or left foot.

\subsection{Vibration Exposure Characteristics}

Whole-body vibration measures defined within the ISO 2631-1 standard including frequency-weighted r.m.s accelerations, CFs, VDVs, and dominant frequencies at the operator-seat interface in each translational axis (x, y and $\mathrm{z}$ ) are summarized in Table 2. Vibration measurements were recorded on seven large LHD vehicles and six small LHD vehicles. 
Table 2. Summary of vibration information measured at the operator/seat interface during LHD vehicle operation.

\begin{tabular}{|c|c|c|c|c|c|c|c|c|c|c|c|c|c|c|}
\hline \multirow[b]{2}{*}{ Size Category } & \multirow{2}{*}{$\begin{array}{c}\text { LHD } \\
\text { Vehicle }\end{array}$} & \multirow{2}{*}{$\begin{array}{c}\circ \\
\text { Test } \\
\text { Duration } \\
\text { (h) }\end{array}$} & \multicolumn{3}{|c|}{$\begin{array}{c}\text { Frequency-weighted r.m.s. } \\
\text { Acceleration Values }{ }^{\mathrm{A}}\end{array}$} & \multicolumn{3}{|c|}{ Dominant Frequency } & \multicolumn{3}{|c|}{ Crest Factor Values } & \multicolumn{3}{|c|}{ Vibration Dose Values ${ }^{A}$} \\
\hline & & & $\begin{array}{c}a_{w x} \\
\left(\mathrm{~m} / \mathrm{s}^{2}\right)\end{array}$ & $\begin{array}{c}\mathrm{a}_{\mathrm{wy}} \\
\left(\mathrm{m} / \mathrm{s}^{2}\right)\end{array}$ & $\begin{array}{c}\mathrm{a}_{\mathrm{wz}} \\
\left(\mathrm{m} / \mathrm{s}^{2}\right)\end{array}$ & $\begin{array}{l}\mathrm{DFx} \\
(\mathrm{Hz})\end{array}$ & $\begin{array}{l}\text { DFy } \\
(\mathrm{Hz})\end{array}$ & $\begin{array}{l}\mathrm{DYz} \\
(\mathrm{Hz})\end{array}$ & CFx & CFy & $\mathrm{CFz}$ & $\begin{array}{l}\text { VDVx } \\
\left(\mathrm{m} / \mathrm{s}^{1.75}\right)\end{array}$ & $\begin{array}{l}\text { VDVy } \\
\left(\mathrm{m} / \mathrm{s}^{1.75}\right)\end{array}$ & $\begin{array}{l}\text { VDVz } \\
\left(\mathrm{m} / \mathrm{s}^{1.75}\right)\end{array}$ \\
\hline \multirow{9}{*}{$\begin{array}{c}\text { Large LHD } \\
\text { Vehicles } \\
\text { (haulage } \\
\text { capacity greater } \\
\text { than } 6 \text { cubic } \\
\text { yards) }\end{array}$} & 1 & 1.03 & 0.84 & 0.50 & 0.81 & 4.00 & 1.00 & 4.00 & 8.36 & 9.03 & 33.66 & 10.42 & 6.24 & 13.18 \\
\hline & 2 & 1.01 & 1.01 & 0.60 & 0.95 & 1.60 & 1.00 & 3.15 & 7.41 & 9.54 & 37.10 & 12.49 & 7.96 & 19.75 \\
\hline & 3 & 0.42 & 1.26 & 0.65 & 1.01 & 1.60 & 1.43 & 3.15 & 6.16 & 6.82 & 11.53 & 7.68 & 3.83 & 7.32 \\
\hline & 4 & 0.80 & 0.63 & 0.49 & 0.60 & 1.25 & 1.00 & 4.00 & 8.85 & 14.61 & 17.28 & 7.58 & 6.35 & 8.07 \\
\hline & 5 & 0.73 & 0.77 & 0.54 & 0.66 & 1.25 & 1.00 & 3.15 & 8.73 & 9.29 & 17.91 & 8.75 & 6.40 & 8.53 \\
\hline & 6 & 1.77 & 0.54 & 0.53 & 0.76 & 1.25 & 1.00 & 3.15 & 13.45 & 11.49 & 30.73 & 8.33 & 8.54 & 12.40 \\
\hline & 7 & 1.72 & 0.73 & 0.62 & 0.87 & 2.00 & 1.00 & 3.15 & 14.82 & 15.66 & 41.01 & 11.44 & 10.37 & 16.87 \\
\hline & Mean & 1.07 & 0.83 & 0.56 & 0.81 & 1.85 & 1.06 & 3.39 & 9.68 & 10.92 & 27.03 & 9.53 & 7.10 & 12.30 \\
\hline & $(\mathrm{SD})$ & $(0.50)$ & $(0.24)$ & $(0.06)$ & $(0.15)$ & $(0.99)$ & $(0.16)$ & $(0.41)$ & (3.2) & (3.2) & (11.35) & $(1.94)$ & $(2.08)$ & (4.73) \\
\hline \multirow{8}{*}{$\begin{array}{c}\text { Small LHD } \\
\text { Vehicles } \\
\text { (haulage } \\
\text { capacity less } \\
\text { than or equal to } \\
6 \text { cubic yards }\end{array}$} & 8 & 0.61 & 0.69 & 0.52 & 0.97 & 1.60 & 1.00 & 4.00 & 8.69 & 9.79 & 8.06 & 8.10 & 5.95 & 10.95 \\
\hline & 9 & 1.05 & 0.68 & 0.46 & 0.79 & 1.60 & 1.00 & 4.00 & 10.81 & 17.11 & 16.54 & 9.84 & 7.16 & 11.83 \\
\hline & 10 & 1.12 & 0.40 & 0.35 & 0.61 & 1.25 & 1.00 & 3.15 & 10.95 & 11.00 & 12.64 & 5.69 & 4.82 & 8.59 \\
\hline & 11 & 1.02 & 0.53 & 0.46 & 0.77 & 1.25 & 1.00 & 3.15 & 9.02 & 7.48 & 12.57 & 6.34 & 5.26 & 9.35 \\
\hline & 12 & 0.79 & 1.19 & 0.83 & 1.86 & 1.25 & 1.00 & 4.00 & 8.47 & 11.59 & 25.54 & 13.55 & 10.46 & 32.70 \\
\hline & 13 & 0.20 & 1.22 & 0.71 & 1.04 & 1.51 & 1.00 & 4.38 & 4.73 & 5.50 & 8.12 & 5.51 & 3.36 & 5.31 \\
\hline & Mean & 0.80 & 0.79 & 0.56 & 1.01 & 1.41 & 1 & 3.78 & 8.78 & 10.41 & 13.91 & 8.17 & 6.17 & 13.12 \\
\hline & $(\mathrm{SD})$ & $(0.35)$ & $(0.34)$ & $(0.18)$ & $(0.45)$ & $(0.18)$ & (0) & $(0.51)$ & $(2.25)$ & (3.99) & $(6.53)$ & (3.11) & $(2.45)$ & (9.85) \\
\hline
\end{tabular}


The dominant frequencies reported in three translational axes ranged from $1.25 \mathrm{~Hz}$ to $4.00 \mathrm{~Hz}$ in the $\mathrm{x}$-axis, $1.00 \mathrm{~Hz}$ to $1.43 \mathrm{~Hz}$ in the $\mathrm{y}$-axis and $3.15 \mathrm{~Hz}$ to $4.38 \mathrm{~Hz}$ in the z-axis (Table 2). A typical frequency spectrum range is shown for one large LHD vehicle and one small LHD vehicle in Figure 1. When considering only large LHD vehicles, the dominant frequency-weighted r.m.s acceleration value occurred in the $\mathrm{x}$-axis for five vehicles and in the z-axis for two vehicles. Considering small LHD vehicles, the dominant frequency-weighted r.m.s acceleration occurred in the z-axis for five vehicles and in the $\mathrm{x}$-axis for one vehicle. However, when the VDV parameter is considered, which is more sensitive to impulsive vibration, the dominant VDV for large LHD vehicles occurred in the z-axis for five of the vehicles and the x-axis for two of the vehicles. Similarly, the dominant VDV for small LHD vehicles occurred in the $\mathrm{z}$-axis for five of the vehicles and the $\mathrm{x}$-axis for one vehicle. All vehicles, with one exception (vehicle 13) had at least one $\mathrm{CF}$ value greater than nine, indicating that both frequency-weighted r.m.s. accelerations and VDVs should be considered when determining health risks [13].

Figure 1. Example $1 / 3$ octave frequency spectrum plots for a large LHD (a) z-axis, (c) y-axis, (e) x-axis; and a small LHD (b) z-axis, (d) y-axis and (f) $\mathrm{x}$-axis.
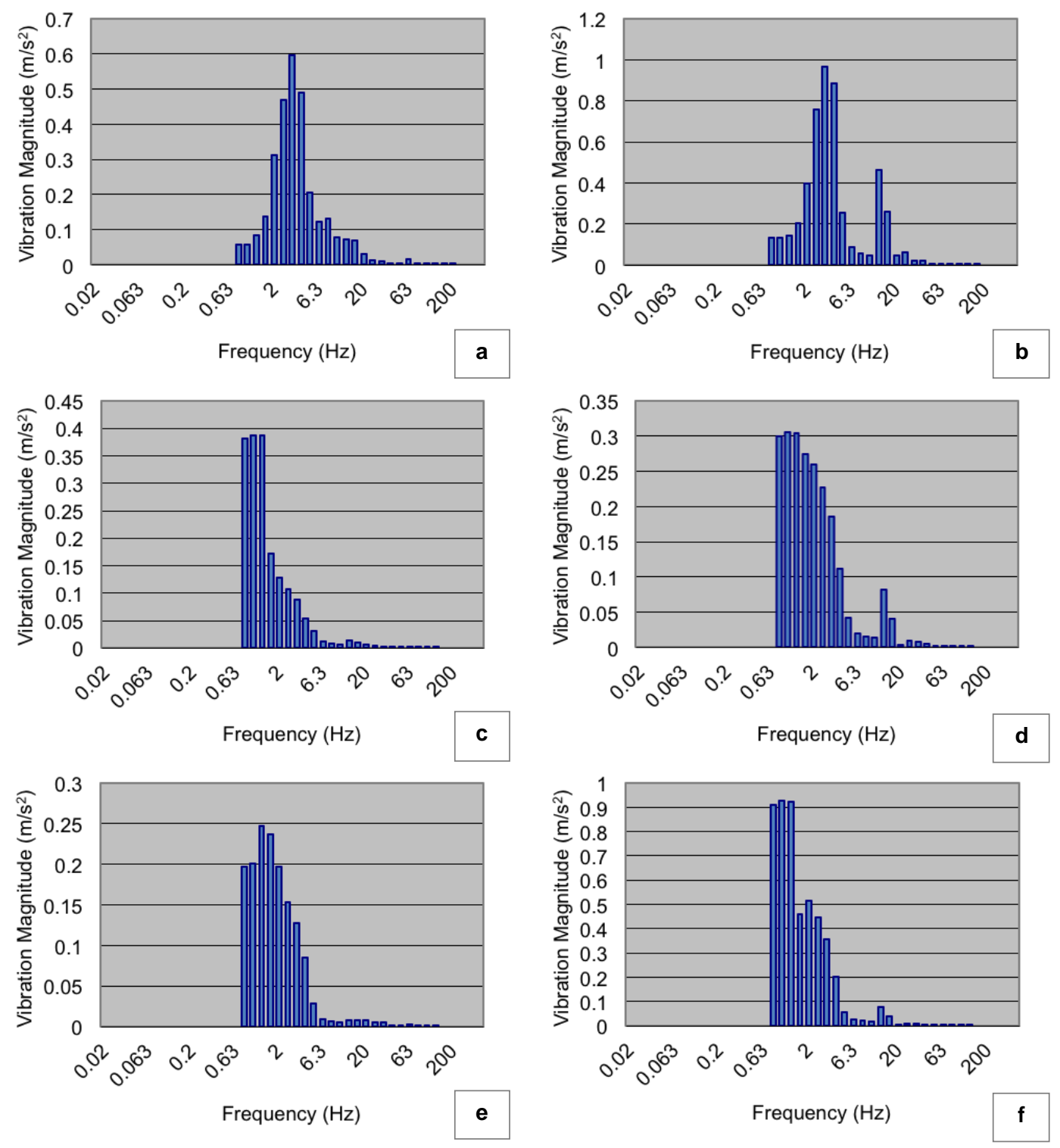


\subsection{Probability of Adverse Health Effects Based on A(8)}

Table 3 summarize the probability of health risks based on the 8-hour HGCZ from the ISO 2631-1 and daily exposure action and limit values published in the EU Directive 2002/44/EC for A(8). According to ISO 2631-1 criterion values two operators were exposed to levels that exceeded the upper limit of the HGCZ; however, only one large LHD operator was exposed to vibration levels that exceeded the EU Directive 2002/44/EC daily limit value. Similarly, three small LHD operators were exposed to frequency-weighted r.m.s. acceleration levels above the ISO 2631-1 HGCZ, while only one small LHD operator's A(8) vibration exposure exceeded the EU Directive daily limit value.

\subsection{Probability of Adverse Health Effects Based on Measures Evaluating Impulsive Vibration}

\subsubsection{VDV total Value Comparisons}

Table 4 summarize the probability of health risks associated with VDV $_{\text {total }}$ based on the ISO 2631-1 HGCZ and the EU Directive 2002/44/EC daily exposure limit value. According to the respective criterion values, four operators of large LHD vehicles experienced vibration levels that exceeded the upper limit of the HGCZ, while only two large LHD operators exceeded the EU Directive daily exposure limit. The findings were similar for small LHD operators with three exceeding the upper boundary of the HGCZ for $\mathrm{VDV}_{\text {total }}$ with only one reaching exposure levels above the EU Directive daily limit value (Table 4).

\subsubsection{Findings from the ISO 2631-5 Analysis}

The risk of adverse health effects to the lumbar spine based on individual operator profiles and typical operator profiles are presented in Table 5. The reported $S_{\text {ed }}$ values and $\mathrm{R}$ factor values predicted that only one operator of a large LHD vehicle (driver 2) was at risk for likely damage to the lumbar spine. Similarly, the reported $S_{\text {ed }}$ values and $\mathrm{R}$ factor values predicted that only one operator of a small LHD vehicle (driver 12) was at risk for likely damage to the lumbar spine. It is noteworthy that the drivers who were identified as being at risk of likely damage to the lumbar spine were identified using both the lifetime and current exposure levels.

\subsubsection{Comparing findings from $\operatorname{VDV}_{\text {total }}$ (ISO 2631-1, EU Directive 2002/44/EC) and $\mathrm{S}_{\text {ed }}$ and R Factor (ISO 2631-5)}

$\mathrm{VDV}_{\text {total }}, \mathrm{S}_{\mathrm{ed}}$ and $\mathrm{R}$ factor are all measures that are used to determine probability of injury when exposed to impulsive vibration (vibration with repeating peaks). When comparing the probability of adverse health effects based on $\mathrm{VDV}_{\text {total }}$ to probability based on the $\mathrm{S}_{\mathrm{ed}}$ and $\mathrm{R}$ factor values, agreement only existed for LHD operator 12 (Table 6). The operator of the small LHD (12) experienced vibration

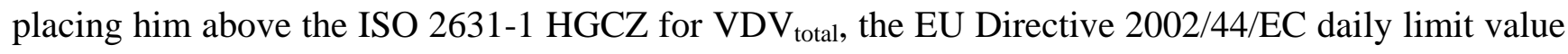
for $\mathrm{VDV}_{\text {total }}$, and the ISO 2631-5 recommended exposure level for Sed. The greatest probability of injury was obtained when referring to the ISO 2631-1 HGCZ for VDV total (7 operators) and the lowest probability was found when ISO 2631-5 criteria were considered ( 2 operators). 
Table 3. Determination of health risk, to the LHD operator, according to ISO 2631-1 HGCZ and European Union Directive daily exposure standards based on the estimated 8-hour equivalent frequency-weighted r.m.s acceleration value, $\mathrm{A}(8)$.

\begin{tabular}{|c|c|c|c|c|c|c|}
\hline $\begin{array}{c}\text { Size } \\
\text { Category }\end{array}$ & $\begin{array}{c}\text { LHD } \\
\text { Vehicle }\end{array}$ & $\begin{array}{c}\text { Duration of } \\
\text { Measurement } \\
\text { (h) } \\
\end{array}$ & $\begin{array}{c}\text { Vibration Magnitude } \\
\text { on Seat (dominant axis) } \\
\left(\mathrm{m} / \mathbf{s}^{2}\right) \\
\end{array}$ & $\begin{array}{l}\mathbf{A}(\mathbf{8})^{\mathbf{A}} \\
\left(\mathbf{m} / \mathbf{s}^{2}\right)\end{array}$ & $\begin{array}{c}\text { ISO 2631-1 } \\
\text { HGCZ }^{\text {B }}\end{array}$ & $\begin{array}{c}\text { EU Directive } \\
\text { (daily exposure) }^{\mathrm{C}}\end{array}$ \\
\hline \multirow{8}{*}{$\begin{array}{c}\text { Large } \\
\text { LHD } \\
\text { Vehicles } \\
\text { (haulage } \\
\text { capacity } \\
\text { greater } \\
\text { than } 6 \\
\text { yards) }\end{array}$} & 1 & 1.03 & 0.84 & 0.78 & $\begin{array}{c}\text { within the } \\
\text { HGCZ }\end{array}$ & $\begin{array}{l}\text { above the } \\
\text { action value }\end{array}$ \\
\hline & 2 & 1.01 & 1.01 & 0.95 & $\begin{array}{l}\text { above the } \\
\text { HGCZ }\end{array}$ & $\begin{array}{l}\text { above the } \\
\text { action value }\end{array}$ \\
\hline & 3 & 0.42 & 1.26 & 1.18 & $\begin{array}{l}\text { above the } \\
\text { HGCZ }\end{array}$ & $\begin{array}{l}\text { above the } \\
\text { limit value }\end{array}$ \\
\hline & 4 & 0.8 & 0.63 & 0.59 & $\begin{array}{l}\text { within the } \\
\text { HGCZ }\end{array}$ & $\begin{array}{l}\text { above the } \\
\text { action value }\end{array}$ \\
\hline & 5 & 0.73 & 0.77 & 0.72 & $\begin{array}{l}\text { within the } \\
\text { HGCZ }\end{array}$ & $\begin{array}{l}\text { above the } \\
\text { action value }\end{array}$ \\
\hline & 6 & 1.77 & 0.76 & 0.71 & $\begin{array}{l}\text { within the } \\
\text { HGCZ }\end{array}$ & $\begin{array}{l}\text { above the } \\
\text { action value }\end{array}$ \\
\hline & 7 & 1.72 & 0.87 & 0.82 & $\begin{array}{l}\text { within the } \\
\text { HGCZ }\end{array}$ & $\begin{array}{l}\text { above the } \\
\text { action value }\end{array}$ \\
\hline & Mean (SD) & $1.07(0.50)$ & $0.88(0.2)$ & $0.82(0.19)$ & $\begin{array}{l}\text { within the } \\
\text { HGCZ }\end{array}$ & $\begin{array}{c}\text { above the } \\
\text { action value }\end{array}$ \\
\hline \multirow{7}{*}{$\begin{array}{l}\text { Small } \\
\text { LHD } \\
\text { Vehicles } \\
\text { (haulage } \\
\text { capacity } \\
\text { less than } \\
\text { or equal } \\
\text { to } 6 \text { yards }\end{array}$} & 8 & 0.61 & 0.97 & 0.91 & $\begin{array}{c}\text { above the } \\
\text { HGCZ }\end{array}$ & $\begin{array}{l}\text { above the } \\
\text { action value }\end{array}$ \\
\hline & 9 & 1.05 & 0.79 & 0.73 & $\begin{array}{l}\text { within the } \\
\text { HGCZ }\end{array}$ & $\begin{array}{l}\text { above the } \\
\text { action value }\end{array}$ \\
\hline & 10 & 1.12 & 0.61 & 0.57 & $\begin{array}{l}\text { within the } \\
\text { HGCZ }\end{array}$ & $\begin{array}{c}\text { above the } \\
\text { action value }\end{array}$ \\
\hline & 11 & 1.02 & 0.77 & 0.72 & $\begin{array}{l}\text { within the } \\
\text { HGCZ }\end{array}$ & $\begin{array}{c}\text { above the } \\
\text { action value }\end{array}$ \\
\hline & 12 & 0.79 & 1.86 & 1.74 & $\begin{array}{c}\text { above the } \\
\text { HGCZ }\end{array}$ & $\begin{array}{l}\text { above the } \\
\text { limit value }\end{array}$ \\
\hline & 13 & 0.2 & 1.22 & 1.14 & $\begin{array}{c}\text { above the } \\
\text { HGCZ }\end{array}$ & $\begin{array}{l}\text { above the } \\
\text { action value }\end{array}$ \\
\hline & Mean (SD) & $0.8(0.35)$ & $1.04(0.45)$ & $0.97(0.43)$ & $\begin{array}{c}\text { above the } \\
\text { HGCZ }\end{array}$ & $\begin{array}{c}\text { above the } \\
\text { action value }\end{array}$ \\
\hline
\end{tabular}

Notes: ${ }^{A}$ The estimated 8-hour equivalent frequency-weighted r.m.s acceleration values are based on $7 \mathrm{~h}$ of driving and mucking, with the vibration exposure listed in this table, and 1 hour off of the vehicle (zero vibration exposure); ${ }^{\mathrm{B}}$ According to ISO 2631-1 the frequency weighted acceleration values corresponding to the lower and upper limits of the HGCZ (for $8 \mathrm{~h}$ of exposure) are $0.45 \mathrm{~m} / \mathrm{s}^{2}$ and $0.90 \mathrm{~m} / \mathrm{s}^{2}$ respectively; ${ }^{\mathrm{C}}$ The $\mathrm{A}(8)$ daily exposure action value and daily exposure limit value established in the European Union Directive 2002/44/EC are $0.5 \mathrm{~m} / \mathrm{s}^{2}$ and $1.15 \mathrm{~m} / \mathrm{s}^{2}$. 
Table 4. Determination of health risk, to the LHD operator, according to ISO 2631-1 HGCZ and European Union Directive daily exposure standards based on the estimated 8-hour vibration dose value, $\operatorname{VDV}_{\text {total }}$.

\begin{tabular}{|c|c|c|c|c|c|c|}
\hline $\begin{array}{c}\text { Size } \\
\text { Category }\end{array}$ & $\begin{array}{c}\text { LHD } \\
\text { Vehicle }\end{array}$ & $\begin{array}{c}\text { Duration of } \\
\text { Measurement } \\
\text { (h) } \\
\end{array}$ & $\begin{array}{c}\text { VDV on seat (dominant } \\
\text { axis) for the measured } \\
\text { duration }\left(\mathrm{m} / \mathrm{s}^{1.75}\right) \\
\end{array}$ & $\begin{array}{c}\mathrm{VDV}_{\text {total }}{ }^{\mathrm{A}} \\
\left(\mathrm{m} / \mathrm{s}^{1.75}\right)\end{array}$ & $\begin{array}{c}\text { ISO 2631-1 } \\
\text { HGCZ }^{\text {B }}\end{array}$ & $\begin{array}{c}\text { EU Directive } \\
\text { (daily exposure) }^{\mathrm{C}}\end{array}$ \\
\hline \multirow{8}{*}{$\begin{array}{l}\text { Large } \\
\text { LHD } \\
\text { Vehicles } \\
\text { (haulage } \\
\text { capacity } \\
\text { greater } \\
\text { than } \\
6 \text { yards) }\end{array}$} & 1 & 1.03 & 13.18 & 21.27 & $\begin{array}{c}\text { above the } \\
\text { HGCZ }\end{array}$ & $\begin{array}{l}\text { above the } \\
\text { limit value }\end{array}$ \\
\hline & 2 & 1.01 & 19.75 & 32.07 & $\begin{array}{c}\text { above the } \\
\text { HGCZ }\end{array}$ & $\begin{array}{l}\text { above the } \\
\text { action value }\end{array}$ \\
\hline & 3 & 0.42 & 7.68 & 15.53 & $\begin{array}{l}\text { within the } \\
\text { HGCZ }\end{array}$ & $\begin{array}{l}\text { above the } \\
\text { action value }\end{array}$ \\
\hline & 4 & 0.8 & 8.07 & 13.9 & $\begin{array}{l}\text { within the } \\
\text { HGCZ }\end{array}$ & $\begin{array}{c}\text { above the } \\
\text { action value }\end{array}$ \\
\hline & 5 & 0.73 & 8.75 & 15.41 & $\begin{array}{c}\text { within the } \\
\text { HGCZ }\end{array}$ & $\begin{array}{l}\text { above the } \\
\text { action value }\end{array}$ \\
\hline & 6 & 1.77 & 12.4 & 17.47 & $\begin{array}{c}\text { above the } \\
\text { HGCZ }\end{array}$ & $\begin{array}{l}\text { above the } \\
\text { action value }\end{array}$ \\
\hline & 7 & 1.72 & 16.87 & 23.96 & $\begin{array}{c}\text { above the } \\
\text { HGCZ }\end{array}$ & $\begin{array}{l}\text { above the } \\
\text { limit value }\end{array}$ \\
\hline & Mean (SD) & $1.07(0.5)$ & $12.39(4.64)$ & $19.94(6.42)$ & $\begin{array}{c}\text { above the } \\
\text { HGCZ }\end{array}$ & $\begin{array}{c}\text { above the } \\
\text { action value }\end{array}$ \\
\hline \multirow{7}{*}{$\begin{array}{c}\text { Small } \\
\text { LHD } \\
\text { Vehicles } \\
\text { (haulage } \\
\text { capacity } \\
\text { less than } \\
\text { or equal } \\
\text { to } \\
6 \text { yards) }\end{array}$} & 8 & 0.61 & 10.95 & 20.19 & $\begin{array}{c}\text { above the } \\
\text { HGCZ }\end{array}$ & $\begin{array}{l}\text { above the } \\
\text { action value }\end{array}$ \\
\hline & 9 & 1.05 & 11.83 & 19.01 & $\begin{array}{c}\text { above the } \\
\text { HGCZ }\end{array}$ & $\begin{array}{l}\text { above the } \\
\text { action value }\end{array}$ \\
\hline & 10 & 1.12 & 8.59 & 13.58 & $\begin{array}{l}\text { within the } \\
\text { HGCZ }\end{array}$ & $\begin{array}{l}\text { above the } \\
\text { action value }\end{array}$ \\
\hline & 11 & 1.02 & 9.35 & 15.13 & $\begin{array}{l}\text { within the } \\
\text { HGCZ }\end{array}$ & $\begin{array}{l}\text { above the } \\
\text { action value }\end{array}$ \\
\hline & 12 & 0.79 & 32.7 & 56.48 & $\begin{array}{l}\text { above the } \\
\text { HGCZ }\end{array}$ & $\begin{array}{l}\text { above the } \\
\text { limit value }\end{array}$ \\
\hline & 13 & 0.2 & 5.51 & 13.35 & $\begin{array}{c}\text { within the } \\
\text { HGCZ }\end{array}$ & $\begin{array}{l}\text { above the } \\
\text { action value }\end{array}$ \\
\hline & Mean (SD) & $0.80(0.35)$ & $13.16(9.82)$ & $22.96(16.66)$ & $\begin{array}{c}\text { above the } \\
\text { HGCZ }\end{array}$ & $\begin{array}{l}\text { above the } \\
\text { limit value }\end{array}$ \\
\hline
\end{tabular}

Notes: ${ }^{\mathrm{A}}$ The eight hour vibration dose values are calculated based on $7 \mathrm{~h}$ of driving and mucking, with the vibration exposure listed in this table, and $1 \mathrm{~h}$ off of the vehicle (zero vibration exposure); ${ }^{\mathrm{B}}$ According to ISO 2631-1 the VDVs corresponding to the lower and upper limits of the HGCZ (for $8 \mathrm{~h}$ of exposure) are $8.5 \mathrm{~m} / \mathrm{s}^{1.75}$ and $17 \mathrm{~m} / \mathrm{s}^{1.75}$ respectively; C According to the European Union Directive 2002/44/EC the VDVs corresponding to the daily exposure action value and daily exposure limit value are $9.1 \mathrm{~m} / \mathrm{s}^{1.75}$ and $21 \mathrm{~m} / \mathrm{s}^{1.75}$ respectively. 
Table 5. Evaluation of health risks associated with vibration containing multiple shocks (ISO-2631-5 analysis).

\begin{tabular}{|c|c|c|c|c|c|c|c|c|c|c|c|c|}
\hline \multirow{2}{*}{$\begin{array}{c}\text { Size } \\
\text { Category }\end{array}$} & \multirow{2}{*}{$\begin{array}{c}\text { LHD } \\
\text { Vehicle }\end{array}$} & \multicolumn{9}{|c|}{ Individual Operator Profiles } & \multicolumn{2}{|c|}{$\begin{array}{c}\text { Typical Operator } \\
\text { Profile** }\end{array}$} \\
\hline & & $\begin{array}{c}\text { Driver } \\
\text { Age } \\
\text { (year) }\end{array}$ & $\begin{array}{c}\text { Daily } \\
\text { Exposure* }^{*} \\
\text { (h) } \\
\end{array}$ & $\begin{array}{c}\text { Yearly } \\
\text { Exposure } \\
\text { (day) } \\
\end{array}$ & $\begin{array}{c}\text { Lifetime } \\
\text { Exposure } \\
\text { (year) }\end{array}$ & $\begin{array}{l}\text { Start Age } \\
\text { (year) }\end{array}$ & $\begin{array}{c}\mathbf{S}_{\text {ed }} \\
(\mathbf{M P a})\end{array}$ & $\begin{array}{c}\text { Injury }^{\mathbf{A}} \\
\text { Probability }\end{array}$ & R Factor & $\begin{array}{c}\text { Injury }^{\text {B }} \\
\text { Probability }\end{array}$ & R Factor & $\begin{array}{c}\text { Injury }^{B} \\
\text { Probability }\end{array}$ \\
\hline Large & 2 & 51 & 7 & 161.5 & 26 & 25 & 0.90 & High & 0.84 & Low & 0.3 & Low \\
\hline LHD & 3 & 43 & 6 & 174.5 & 21 & 22 & 0.41 & Low & 0.39 & Low & 1.13 & High \\
\hline Vehicles & 4 & 53 & 7 & 182.5 & 25 & 28 & 0.30 & Low & 0.34 & Low & 0.52 & Low \\
\hline (haulage & 5 & 50 & 8 & 180 & 20 & 30 & 0.28 & Low & 0.30 & Low & 0.36 & Low \\
\hline capacity & 6 & 64 & 10.25 & 142 & 34 & 20 & 0.31 & Low & 0.35 & Low & 0.33 & Low \\
\hline greater & 7 & 42 & 7.5 & 182.5 & 20 & 22 & 0.46 & Low & 0.46 & Low & 0.36 & Low \\
\hline $\begin{array}{l}\text { than } 6 \\
\text { yards) }\end{array}$ & $\begin{array}{l}\text { Mean } \\
(\mathrm{SD})\end{array}$ & $\begin{array}{c}50.5 \\
(7.97) \\
\end{array}$ & $7.63(1.45)$ & $\begin{array}{c}170.5 \\
(16.05) \\
\end{array}$ & $\begin{array}{l}24.33 \\
(5.39) \\
\end{array}$ & $\begin{array}{c}24.5 \\
(3.89) \\
\end{array}$ & $\begin{array}{c}0.44 \\
(0.23) \\
\end{array}$ & Low & $\begin{array}{c}0.45 \\
(0.20)\end{array}$ & Low & $\begin{array}{c}0.50 \\
(0.32) \\
\end{array}$ & Low \\
\hline Small & 8 & 49 & 6 & 160 & 13 & 36 & 0.27 & Low & 0.24 & Low & 0.58 & Low \\
\hline LHD & 9 & 44 & 6.75 & 180 & 8 & 36 & 0.45 & Low & 0.39 & Low & 0.33 & Low \\
\hline Vehicles & 10 & 22 & 9 & 161.5 & 1 & 21 & 0.23 & Low & 0.11 & Low & 0.55 & Low \\
\hline (haulage & 11 & 49 & 6 & 160 & 13 & 36 & 0.21 & Low & 0.21 & Low & 0.27 & Low \\
\hline capacity & 12 & 44 & 3 & 265 & 26 & 18 & 1.23 & High & 1.27 & High & 0.26 & Low \\
\hline less than & 13 & 57 & 8 & 226 & 20 & 37 & 0.32 & Low & 0.41 & Low & 1.73 & High \\
\hline $\begin{array}{l}\text { or equal } \\
\text { to } 6 \text { yards }\end{array}$ & $\begin{array}{l}\text { Mean } \\
(\mathrm{SD})\end{array}$ & $\begin{array}{c}44.17 \\
(11.86)\end{array}$ & $6.46(2.06)$ & $\begin{array}{l}192.08 \\
(43.83)\end{array}$ & $\begin{array}{l}13.50 \\
(8.78)\end{array}$ & $\begin{array}{l}30.67 \\
(8.71)\end{array}$ & $\begin{array}{c}0.45 \\
(0.39)\end{array}$ & Low & $\begin{array}{c}0.44 \\
(0.42)\end{array}$ & Low & $\begin{array}{c}0.62 \\
(0.56)\end{array}$ & Low \\
\hline
\end{tabular}

Notes: nothing report for LHD operator 1 as personal data were not provided for the calculations; * Daily vibration exposure varied due to differences in work shift length and assigned working tasks; A According to ISO 2631-5 the Sed below 0.5 Mpa is associated with a low probability of an adverse health effect, a value above 0.8 MPa is associated with a high probability of an adverse health effect; B According to ISO 2631-5 an R factor value of 0.8 is associated with a low probability of an adverse health effect, a value above 1.2 is associated with a high probability of an adverse health effect; ** The typical operator profile used the same daily exposure ( $8 \mathrm{~h})$, yearly exposure (192 days/year), and lifetime exposure ( 30 years). 
Table 6. Summary: Probability of health risk based on ISO 2631-1, EU Directive 2002/EC/44 and ISO 2631-5 criterion values. "O" is used to compare measures evaluating vibration exposure with impact shocks and " $X$ " is used to compare $A(8)$ measures.

\begin{tabular}{|c|c|c|c|c|c|c|c|c|}
\hline \multirow{2}{*}{ Size Category } & \multirow{2}{*}{$\begin{array}{c}\text { LHD } \\
\text { Vehicle }\end{array}$} & \multicolumn{2}{|c|}{ ISO 2631-1* } & \multicolumn{2}{|c|}{$\begin{array}{c}\text { EU Directive** } \\
2002 / 44 / \mathrm{EC}\end{array}$} & \multicolumn{3}{|c|}{ ISO $2631-5 * * *$} \\
\hline & & $\mathbf{A}(\mathbf{8})$ & $\mathbf{V D V}_{\text {total }}$ & $\mathbf{A}(\mathbf{8})$ & $\mathbf{V D V}_{\text {total }}$ & $\mathbf{S}_{\text {ed }}$ & $\begin{array}{c}\text { R Factor } \\
\text { (IOP) }\end{array}$ & $\begin{array}{c}\text { R Factor } \\
\text { (TOP) }\end{array}$ \\
\hline \multirow{7}{*}{$\begin{array}{l}\text { Large LHD Vehicles } \\
\text { (haulage capacity greater } \\
\text { than } 6 \text { yards) }\end{array}$} & 1 & & $\mathbf{O}$ & & $\mathbf{O}$ & & & \\
\hline & 2 & $\mathbf{x}$ & $\mathbf{O}$ & & & $\mathbf{O}$ & & \\
\hline & 3 & $\mathbf{x}$ & & $\mathbf{X}$ & & & & $\mathbf{O}$ \\
\hline & 4 & & & & & & & \\
\hline & 5 & & & & & & & \\
\hline & 6 & & $\mathbf{O}$ & & & & & \\
\hline & 7 & & $\mathbf{O}$ & & $\mathbf{O}$ & & & \\
\hline \multirow{6}{*}{$\begin{array}{c}\text { Small LHD Vehicles } \\
\text { (haulage capacity less than } \\
\text { or equal to } 6 \text { yards }\end{array}$} & 8 & $\mathbf{X}$ & $\mathbf{O}$ & & & & & \\
\hline & 9 & & $\mathbf{O}$ & & & & & \\
\hline & 10 & & & & & & & \\
\hline & 11 & & & & & & & \\
\hline & 12 & $\mathbf{X}$ & $\mathbf{O}$ & $\mathbf{X}$ & o & $\mathbf{O}$ & O & \\
\hline & 13 & $\mathbf{X}$ & & & & & & $\mathbf{O}$ \\
\hline
\end{tabular}

Notes: * above the 8-hour health guidance caution zone; ** above the daily exposure limit value; *** above the criterion values associated with a high probability of injury to the lumbar spine.

\section{Discussion}

\subsection{Vibration Exposure and Musculoskeletal Injury}

The first objective of this study was to determine the body area associated with musculoskeletal discomfort during the operation of large and small LHD vehicles. Nine of 13, six of 13, and eight of 13 reported pain/discomfort in the head/neck, upper back and lower back respectively. Of those, only two operators indicated the pain/discomfort to be very severe and both were exposed to vibration which placed them above the ISO 2631-1 HGCZ $\left[\operatorname{VDV}_{\text {total }}\right.$ and $\left.\mathrm{A}(8)\right]$, while only one (operator 2) experienced vibration above the ISO 2631-1 $\mathrm{S}_{\mathrm{ed}}$ criterion value. However, the contribution of sustained awkward body postures to musculoskeletal injury development must also be considered. Due to limited sightlines, LHD operators sit with their trunk and neck rotated and their trunk in a forward flexed, and laterally bent position [12,17]. Furthermore, constrained sitting postures coupled with WBV increases the risk of intervertebral disc failure, spinal degeneration and LBP [1]. Hence, the magnitude and duration of vibration exposure are not the only risk factors associated with musculoskeletal injury to LHD operators. For example, in a study of large LHD operators Eger and colleagues found an operator's musculoskeletal injury risk score to be correlated with greater vibration exposure, poor working postures and higher levels of spinal compression [18]. It is also important to remember WBV exposure and the associated risk of musculoskeletal injury are also dependent on other factors such as driving speed, road surface, backrest contact, and muscle fatigue $[10,19,20]$. 


\subsection{Standard Agreement Comparison}

The second objective of this paper was to compare the probability of health risk associated with frequency weighted r.m.s. acceleration A(8) criterion exposure values in ISO 2631-1 and the EU Directive 2002/44/EC. And the third objective was to compare health risk probability from exposure to

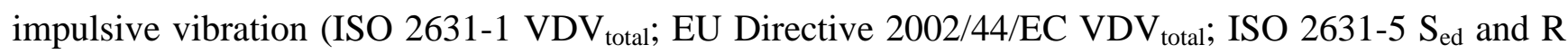
Factor). Only two LHD operators were exposed to vibration associated with a higher probability of health risk according to criterion values for A(8) in ISO 2631-1 and EU Directive 2002/44/EC (Table 6).

A(8) vibration exposure exceeded both the ISO 2631-1 HGCZ and the EU Directive 2002/44/EC criterion values for two operators, and an additional three operators were above the HGCZ. Therefore, the criterion values in the 2631-1 HGCZ are more conservative. When the probability of adverse health effects was based on VDV total values, ISO 2631-1and the EU Directive 2002/44/EC agreed that three operators had exposures above the respective criterion values. However, four additional operators had exposures that exceeded the ISO HGCZ suggesting again that ISO 2631-1 is a more conservative measure.

ISO 2631-5 was developed specifically to address the probability of injury to the lumbar spine associated with WBV containing multiple shocks [16], where a transient shock is distinguished by short duration, sporadic nature, and extremely high amplitudes in contrast to widely studied steady state vibration [21]. Similarly, the VDV measure was developed to provide a more accurate assessment of injury associated with vibration exposure with high crest factors resulting from peaks greater than the average magnitude of vibration. For example, ISO 2631-1 suggests multiple shocks are present in vibration signals where crest factors exceed nine [13] and in the current study, crest factors in all three translational axes regularly exceeded nine (Table 2).

Therefore, it is not flawed to suggest that VDV measures and ISO 2631-5 measures might suggest a similar probability of injury; however, very little agreement was found in this study. Criterion values associated with a high probability of adverse health effects were in agreement based on ISO 2631-1 HGCZ for $\mathrm{VDV}_{\text {total }}$ and ISO 2631-1 $\mathrm{S}_{\text {ed }}$ in only two cases (LHD 2; LHD 12), and the EU directive and ISO 2631-5 in only one case (LHD 12). Furthermore, there was only one case when a high probability of injury was suggested based on ISO and EU directive criterion values for VDV total and ISO 2631-5 criterion values for $S_{e d}$ and $R$ factor (LHD 12). Eger and colleagues reported similar results in a smaller sample population of seven large LHD vehicle operators [5]. More specifically, the LHD operators had a daily exposure that placed them within the ISO 2631-1 HGCZ but below both the $S_{\text {ed }}$ and $\mathrm{R}$ factor criterion value associated with a low probability of injury to the lumbar spine [5], suggestion again that ISO 2631-1 is more conservative. Moreover, researchers quantifying WBV exposure in locomotive operators reported similar results. Johanning and colleagues also concluded that predicted health risks were much lower according to variables defined within the ISO 2631-5 standard in a sample population of 20 locomotive operators despite the presence of multiple shocks [22]. More specifically, the frequency weighted r.m.s. acceleration values indicated that many operators were exposed to vibration levels above the HGCZ in the ISO 2631-1 standard, whereas the ISO 2631-5 standard predicted that fewer operators were at risk of adverse health effects [22]. Similarly, Cooperrider and Gordon reported that the ISO 2631-5 standard suggested a lower probability of an adverse health effect compared to the ISO 2631-1 evaluation method in a sample population of 
locomotive operators [23]. The researchers reported that the estimated $\mathrm{VDV}_{\text {total }}$ for four operators exceeded the HGCZ, whereas the $S_{\text {ed }}$ values suggested low probabilities of adverse health effects [23]. Contrary to these findings, Alem reported higher health risk probability based on analysis using the ISO 2631-5 report compared to the ISO 2631-1 report in a sample population of army vehicles operators [15]. However, the sample vibrations were selected from a database, which included vibration signals that had a very high shock content and only average frequency-weighted r.m.s. acceleration values [15]. Therefore, Alem's findings are not surprising based on the selection process used to identify the vibration cases.

The discrepancy between the probabilities of health risks obtained when considering $\operatorname{VDV}_{\text {total }}$ values (ISO 2631-1 HGCZ; EU Directive 2002/44/EC) and ISO 2631-5 $\mathrm{S}_{\text {ed }}$ and R factor criterion values should be explored through larger epidemiological studies. For example, the daily exposure limit values in the EU directive are higher than the 8-hour HGCZ upper boundary. Therefore, fewer operators in this study were exposed to vibration levels that exceeded the EU directive, leading to greater agreement between the EU directive and ISO 2631-5 with regards to probability of health risk. However, there is not enough evidence to determine if the EU Directive 2002/44/EC and ISO 2631-5 criterion values are more appropriate than ISO 2631-1 when evaluating spinal health risks associated with LHD vehicle operators. In fact it might be more appropriate to suggest a posture correction factor is required for all the standards given the increase risk of injury to the back and neck when twisted/flexed and exposed to vibration. For example, sideways sitting forklift operators had a three-fold increase in neck injury compared to forward sitting operators [24], bus drivers in the highest category for ergonomic risk factors had a four-fold increase in in developing neck/back pain [25], and agricultural tractor drivers exposed to vibration with high postural demands had significantly greater back/neck injury risk than drivers in the low posture demands category [26]. Therefore, more evidence is needed to determine the link between current criterion values in the respective standards, the contribution of other risk factors such as poor posture, and musculoskeletal injury to the back/spine. This will involve monitoring the occupational health of workers frequently exposed to WBV containing multiple shocks along with their exposure to other risk factors such as awkward postures, and correlating these data with probable heath risks based on $\mathrm{VDV}_{\text {total }}, \mathrm{R}$ factor and $\mathrm{S}_{\text {ed }}$ values [15].

\subsection{Injury Probability and LHD Size}

The final objective of this paper was to determine if the probability of adverse health effects are different for small and large LHD operators. Across all assessment methods, there was no major difference in probability of injury risk between the large and small LHD vehicle operators (Table 6). The mean $\mathrm{A}(8)$ value was $0.97 \pm 0.43 \mathrm{~m} / \mathrm{s}^{2}$ and $0.82 \pm 0.19 \mathrm{~m} / \mathrm{s}^{2}$ for the small and large LHD vehicles respectively. Likewise, the estimated mean $\mathrm{VDV}_{\text {total }}$ for small LHD vehicles was $22.96 \pm 16.66 \mathrm{~m} / \mathrm{s}^{1.75}$ and for large LHD vehicles was $19.9 \pm 6.42 \mathrm{~m} / \mathrm{s}^{1.75}$. Thus, when comparing small and large LHD vehicles, both the mean $\mathrm{A}(8)$ value and the $\mathrm{VDV}_{\text {total }}$ were slightly higher for small LHD operators; however, daily exposure criterion values in the standards discussed in this paper did not suggest a different probability of injury. Similarly, the mean $S_{\text {ed }}$ value for small LHD vehicles was $0.45 \pm 0.39 \mathrm{MPa}$ and for large LHD vehicles was $0.44 \pm 0.23 \mathrm{MPa}$, and the estimated mean R-value (TOP) for small vehicles was $0.62 \pm 0.56$ and for large vehicle was $0.50 \pm 0.32$. Consequently, adverse 
health risks predicted by the ISO 2631-5 standard were also comparable for small and large LHD vehicle operators.

\subsection{Interventions}

Based on the more conservative standard, ISO 2631-1, over half the LHD operators in this study were exposed to vibration above the 8-hour HGCZ indicating health risks are likely. Therefore, mobile equipment operators might benefit from interventions intended to reduce WBV exposure. Potential strategies might include, but are not limited to, maintaining underground roadways [20,27,28], reducing speed where roadways are uneven and jagged [20,29], assuring appropriate vehicle maintenance [20,30], and installing ergonomically correct damped operator seating [29,31]. The benefits of several of the above recommended interventions, and new technologies aimed at vibration reduction were clearly illustrated in a recent study [29]. For example, A(8) values decreased by $15 \%$ when ride control (engineering intervention designed to decrease the transmission to the cab, was engaged. A further $6 \%$ decrease was reported when speed was reduced by avoiding fourth gear, and an additional 13\% decrease was reported when the LHD was driven over maintained roads [29]. Installing a seat suited to the operating environment, capable of attenuating vibration is also critical to decrease the risk of spinal degeneration and related musculoskeletal injury and associated back pain $[29,32]$. Interventions aimed at improving driving posture should also be considered including the use of rotating seats, improved cab ergonomics and collision avoidance systems [12,18,33,34].

\subsection{Limitations and Future Research}

Health criterion values in ISO 2631-1, ISO 2631-5 and EU Directive 2002/44/EC were used to determine the probability of adverse health effects associated with exposure to WBV when operating LHD vehicles in an underground mine. Although these methods are established in the literature they are not without criticism. According to Griffin [35] many WBV standards have set limit and action values; however, there are no dose response data to support the probability of any specific disorder related to the magnitude, frequency, direction, and duration of exposure to vibration. Moreover, language in ISO 2631-5 indicates the models and criterion values in the standard have yet to be epidemiologically validated [16]. Therefore, epidemiological studies are required to determine if a link exists between exposure to WBV above any of the criterion values in ISO 2631-1, ISO 2631-5, and EU Directive 2002/44/EC and the development of adverse health effects such as low-back back or spinal injury. Until such evidence is found there will always be speculation regarding the appropriateness of using one evaluation method over the other. That being said, epidemiological data does support a moderate link between exposure to WBV and an increased risk for low back pain, and degenerative changes in the spinal system [36,37], but more data is required to determine if existing criterion values for exposure are appropriate. Thus, until new epidemiological data can confirm the "dose of WBV" clearly linked with injury development it is prudent to protect workers from exposure to WBV by instituting best practices for exposure reduction and medical surveillance [35]. 


\section{Experimental Section}

\subsection{Selecting LHD Vehicles and Mine Sites}

Researchers from Laurentian University and members of the technical advisory committee for underground equipment from the Mines and Aggregates Safety and Health Association (MASHA) of Ontario, Canada, approached several northern Ontario mine companies concerning their possible participation in this study. Testing occurred at five mining sites operated by three different mining companies. LHD vehicles were selected from a sample of convenience. Seven LHD vehicles (different makes and models) with a bucket haulage capacity greater than $4.6 \mathrm{~m}^{3}$ and six LHD vehicles (different makes and models) with haulage capacity less than $4.6 \mathrm{~m}^{3}$ were tested. LHDs are used to move ore and rock throughout an underground mine and the operator sits sideways to the direction of travel.

\subsection{Selecting LHD Operators}

Load-haul-dump vehicle operators were selected from a sample of convenience. Participating mine sites allowed researchers to notify LHD operators about the current study. Thirteen LHD operators (all male) with mean age, work experience, mass, and height of $47 \pm 10$ years, $19 \pm 10$ years, $90 \pm 14 \mathrm{~kg}$ and $1.80 \pm 0.06 \mathrm{~m}$ agreed to participate in the current study. Prior to their involvement, participants were asked to sign consent forms approved by Laurentian University's Research Ethics Board. Participants also provided information in the form of a questionnaire detailing work experience (vehicle types driven; age of first exposure to vibration; daily vibration exposure; years of exposure to vibration), and work related musculoskeletal pain/discomfort. Operators were shown a picture with a body map indicating the body region for the head, neck, upper back, lower back, right/left shoulder, right/left elbow, right/left wrist/hand, right/left thigh, right/left knee, and right/left ankle/foot. Operators were then asked to mark the region on the body associated with work related discomfort in the last six-months and indicate the severe of the pain/discomfort between 1-4 with 1 representing mild pain/discomfort and 4 representing very severe pain/discomfort. To simplify presentation, reports were later grouped as follows along with the mean severity score; $\mathrm{H} / \mathrm{N}=$ head/neck; UB = upper back; $\mathrm{LB}=$ lower back; R-Arm = right shoulder, right elbow and/or right wrist/hand; L-Arm = left shoulder, left elbow, and/or left wrist/hand; R-Leg = right thigh, right knee, and/or right foot; L-leg = left thigh, left knee, and/or left foot. The questionnaire was completed at the mine site but before starting vibration measurement.

\subsection{WBV Measurement and Collection Procedures}

Researchers asked the participating LHD vehicle operators to muck with the LHD vehicle in their designated work area for approximately 1-hour before returning to another designated area to remove the testing equipment. Mucking is a cyclical process that involves loading the LHD vehicle with ore and rock, driving the vehicle to a dumping zone, and then driving back to the loading zone empty in order to repeat the loading and dumping process. The time to complete one cycle varied according to the mine layout due to the relative locations of the development heading and dumping zone, tunnel width, road grade, and number of sharp left or right turns in the road bed. Most LHD vehicle operators 
completed one mucking cycle between $5 \mathrm{~min}$ and $10 \mathrm{~min}$. Accordingly, the number of work cycles completed within the 1-hour window varied between participants and typically included 6 to 12 mucking cycles.

Whole-body vibration exposure measurements were recorded according to common international standards [13,16,38]. Measurements were recorded at the operator-seat interface with a Series 2, $10 \mathrm{~g}$ tri-axial accelerometer (NexGen Ergonomics, Montreal, Quebec, Canada) in combination with a P3X8-2C DataLOG II datalogger (Biometrics, Gwent, United Kingdom). The accelerometer measured vibration in the fore-and-aft (x-axis), lateral (y-axis), and vertical (z-axis) axes with less than 5\% cross talk.

The Series 2 tri-axial accelerometer was mounted in a rubber seat pad and secured to the seat surface so that it was fixed between the buttock of the operator and the seat. Vibration data were recorded at $500 \mathrm{~Hz}$ using a 13-bit analog-to-digital conversion with a resulting resolution of $0.0025 \mathrm{~g}$ at the $\pm 10 \mathrm{~g}$ full-scale range. The raw WBV signals were recorded and saved to a SD memory card with a $512 \mathrm{MB}$ storage capacity used by the datalogger. Subsequently, the raw data were transferred to an Intel ${ }^{\circledR}$ Pentium ${ }^{\circledR} 4$ computer and analyzed with Vibration Analysis Tool Set (VATS) version 3.1.0 software developed by NegGen Ergonomics Incorporated (Montreal, Quebec, Canada).

\subsection{WBV Analysis}

\subsubsection{Analyses Conducted in Accordance with ISO 2631-1 and EU Directive 2002/44}

Whole-body vibration analyses were conducted in accordance with procedures and guidelines outlined in ISO 2631-1 [13]. In compliance with this standard, frequency-weighted r.m.s accelerations were calculated for three orthogonal axes $\left(a_{w x}, a_{w y}\right.$, and $\left.a_{w z}\right)$ [13]. Appropriate frequency-weighting curves ( $\mathrm{x}$-axis $\mathrm{W}_{\mathrm{d}}$; $\mathrm{y}$-axis $\mathrm{W}_{\mathrm{d}}$; $\mathrm{z}$-axis $\mathrm{W}_{\mathrm{k}}$ ) and scaling factors for health $\left(\mathrm{K}_{\mathrm{x}, \mathrm{y}}=1.4\right.$ and $\mathrm{K}_{\mathrm{z}}=1$ ) were applied to each axis [13]. A vector sum of the frequency-weighted r.m.s acceleration (av) was also calculated [13].

The absence or presence of transient shocks was initially evaluated by calculating peak accelerations in each axis ( $\mathrm{x}, \mathrm{y}$ and $\mathrm{z}$ axes), which were used to calculate $\mathrm{CFs}\left(\mathrm{CF}_{\mathrm{x}}, \mathrm{CF}_{\mathrm{y}}\right.$ and $\left.\mathrm{CF}_{\mathrm{z}}\right)$ [13]. Next, vibration dose values (VDVs) in each translational axis $\left(\operatorname{VDV}_{\mathrm{x}}, \mathrm{VDV}_{\mathrm{y}}\right.$ and $\left.\mathrm{VDV}_{\mathrm{z}}\right)$ were calculated and considered whenever the crest factors exceeded nine [13]. Although vibration at the operator-seat interface was continuously recorded, all aforementioned vibration measures $\left(\mathrm{a}_{\mathrm{wx}}, \mathrm{a}_{\mathrm{wy}}\right.$, and $\mathrm{a}_{\mathrm{wz}}, \mathrm{a}_{\mathrm{v}}$ : peak accelerations; $\mathrm{CF}_{\mathrm{x}}, \mathrm{CF}_{\mathrm{y}}, \mathrm{CF}_{\mathrm{z}}, \mathrm{VDV}_{\mathrm{x}}, \mathrm{VDV}_{\mathrm{y}}, \mathrm{VDV}_{\mathrm{z}}$ ) were also calculated for successive 5-minute intervals and averaged over the entire trial to result in more representative crest factor values.

Lastly, the 8-hour equivalent frequency-weighted r.m.s. acceleration $\mathrm{A}(8)$ and the 8-hour equivalent vibration dose value $\left(\mathrm{VDV}_{\text {total }}\right)$ were calculated in accordance with the ISO 2631-1 report [13] and previously reported assumptions [5]. Eger and associates estimated that daily LHD vehicle operation is approximately $7 \mathrm{~h}$ in an 8-hour shift [5]. The remaining time accounts for breaks, time traveling to and from the underground site (walking or personnel carrier), and moving to designated underground work areas [5].

The 8-hour equivalent frequency-weighted r.m.s. acceleration value $\mathrm{A}(8)$ and $\mathrm{VDV}_{\text {total }}$ were subsequently compared to the ISO 2631-1 HGCZ and the EU Directive 2002/44/EC daily exposure 
action limit and limit value. The upper and lower limits of the ISO $2631-1 \mathrm{HGCZ}$ are $0.45 \mathrm{~m} / \mathrm{s}^{2}$ and $0.90 \mathrm{~m} / \mathrm{s}^{2}$ respectively for $\mathrm{A}(8)$ and $8.5 \mathrm{~m} / \mathrm{s}^{1.75}$ and $17 \mathrm{~m} / \mathrm{s}^{1.75}$ respectively for $\mathrm{VDV}_{\text {total }}$ [13]. The limit values are slightly greater according to EU Directive 2002/44/EC. The A(8) daily exposure action value and daily exposure limit values are $0.5 \mathrm{~m} / \mathrm{s}^{2}$ and $1.15 \mathrm{~m} / \mathrm{s}^{2}$ respectively while the VDV daily exposure action value and daily exposure limit value are $9.1 \mathrm{~m} / \mathrm{s}^{1.75}$ and $21 \mathrm{~m} / \mathrm{s}^{1.75}$ respectively [38].

\subsubsection{Analyses Conducted in Accordance with ISO 2631-5}

ISO 2631-5 is concerned with probable health risks to the lumbar spine from exposure to vibration containing multiple shocks. A tri-axial accelerometer at the operator/seat interface is used to determine the number and magnitude of peaks associated with the WBV exposure [16]. These data are used to calculate the daily equivalent static compression dose at the lumbar spine $\left(S_{\text {ed }}\right)$. A risk factor based on variables such as driver age, daily exposure, yearly exposure, lifetime exposure, and starting age was subsequently computed using two approaches. An individual operator profile (IOP), R factor was determined from each operator's age, daily, yearly and lifetime exposure to WBV. Whereas a lifetime $\mathrm{R}$ factor was determined using a typical operator profile (TOP) estimated to represent WBV exposure levels accumulated for operation of a LHD over a lifetime [18].

\subsubsection{Comparison of Health Risks Probability}

The probability of adverse health effects across the standards were compared for A(8), VDV, $S_{\text {ed }}$ and R-factor according to Table 7. Agreement of ISO 2631-1 and EU Directive 2002/44/EC with respect to probability of adverse health effects for $\mathrm{A}(8)$ were compared. The probability of health risks based on $\mathrm{VDV}_{\text {total }}, S_{\text {ed }}$, and R Factor values were also compared since each of these measures considers injury risk due to impulse shocks. These measured were selected as they represent a common method often reported in the literature (ISO 2631-1), a required standard when evaluating vibration exposure in the European Union (EU Directive 2002/44/EC), and a relatively new standard promoted to evaluate vibration containing impulse shocks (ISO 2631-5).

Table 7. Summary of the measures calculated and compared to determine agreement with respect to probability of adverse health effects.

\begin{tabular}{ccccccc}
\hline \multirow{3}{*}{ Comparison } & \multicolumn{5}{c}{ Vibration Exposure Evaluation Methods } \\
\cline { 2 - 7 } & \multicolumn{2}{c}{ ISO 2631-1 } & EU Directive 2002/44/EC & \multicolumn{2}{c}{ ISO 2631-5 } \\
\cline { 2 - 7 } & $\mathrm{A}(8)$ & $\mathrm{VDV}$ & $\mathrm{A}(8)$ & $\mathrm{VDV}$ & $\mathrm{S}_{\mathrm{ed}}$ & $\mathrm{R}_{\text {Factor* }}$ \\
\hline 1 & $\mathrm{X}$ & $\mathrm{X}$ & $\mathrm{X}$ & $\mathrm{X}$ & $\mathrm{X}$ & $\mathrm{X}$ \\
\hline
\end{tabular}

Note: * $\mathrm{R}$ factor calculated based on typical WBV exposure levels accumulated while operating LHD vehicles over their lifetimes (TOP).

\section{Conclusions}

Health risks associated with the operation of large and small LHD vehicles were evaluated according to ISO 2631-1, EU Directive 2002/44/EC and ISO 2631-5 criteria. Probability of health risks to the LHD operators were suggested to be greatest based on daily exposure criterion values 
published in ISO 2631-1, and lowest based on ISO 2631-5 criterion values. Epidemiological studies are required to determine if the current criterion values in ISO 2631-1; EU Directive 2002/44/EC and ISO 2631-5 are solely appropriate to predict musculoskeletal injury amongst LHD operators since they are also exposed to other injury risk factors not accounted for in the standards. Thus, the inclusion of a posture correction factor should be considered in future revisions/updates to the standards. In the meantime, the more conservative ISO 2631-1 should be used to evaluate the probability of adverse health risks and interventions aimed at supporting a neutral driving posture and decreased vibration exposure should be implemented.

\section{Acknowledgments}

The Workplace Safety and Insurance Board of Ontario, Canada provided financial support for this research project. The research team would also like to thank Workplace Safety North, the Ontario mining industry, and the miners who participated in this study. The authors would also like to thank Sylvain Grenier for early assistance with data collection.

\section{References}

1. Bovenzi, M.; Hulshof, C.T.J. An updated review of epidemiological studies between exposure to whole-body vibration and low back pain. J. Sound Vib. 1998, 215, 595-611.

2. McPhee, B. Ergonomics in mining. Occ. Med. 2004, 54, 297-303.

3. Village, J.; Morrison, J.B.; Leong, D. Whole-body vibration in underground load-haul-dump vehicles. Ergonomics 1989, 32, 1167-1183.

4. Eger, T.; Salmoni, A.; Cann, A.; Jack, R. Whole-body vibration exposure experienced by mining equipment operators. Occup. Ergon. 2006, 6, 121-127.

5. Eger, T.; Stevenson, J.; Boileau, P.É.; Salmoni, A.; VibRG (Vibration Research Group). Predictions of health risks associated with the operation of load-haul-dump mining vehicles: Part 1-Analysis of whole-body vibration exposure using ISO 2631-1 and ISO 2631-5 standards. Int. J. Ind. Ergon. 2005, 38, 726-738.

6. Kitazaki, S.; Griffin, M. Resonance behavior of the seated human body and effects of posture. J. Biomech. 1998, 3, 143-149.

7. Mansfield, N. Human Response to Vibration; CRC Press: Boca Raton, FL, USA, 2005.

8. Smith, D.; Leggat, P. Whole-body vibration: Health effects, measurement and minimization. Prof. Saf. 2005, 7, 35-40.

9. Siedel, H. Selected health risks caused by long-term, whole-body vibration. Am. J. Ind. Med. 1993, 23, 589-604.

10. Seidel, H. On the relationship between whole-body vibration exposure and spinal health risk. Ind. Health 2005, 43, 361-377.

11. Blüthner, R.; Seidel, H.; Hinz, B.; Schust, M. Timing of back muscles during whole-body vibration with transients-Its significance for the internal spinal load. J. Low Freq. Noise V. A. 1997, 17, 215-226. 
12. Godwin, A.; Eger, T.; Salmoni, A.; Grenier, S.; Dunn, P. Postural implications of obtaining line-of-sight for seated operators of underground mining load-haul-dump vehicles. Ergonomics 2007, 50, 197-207.

13. Mechanical Vibration and Shock-Evaluation of Human Exposure to Whole-Body Vibration-Part 1: General Requirements (ISO 2631-1); International Organization for Standardization (ISO): Geneva, Switzerland, 1997.

14. Morrison, J.; Robinson, D.; Roddan, G.; Nicol, J.; Springer, M. Development of a Standard for the Health Hazard Assessment of Mechanical Shocks and Repeated Impact in Army Vehicles: Phase 5; Contract Report No. Cr-98-1; B.C. Research Inc. for U.S. Army Aeromedical Research Laboratory: Fort Rucker, AL, USA, 1998.

15. Alem, N. Application of the new ISO 2631-5 to health hazard assessment of repeated shocks in U.S. army vehicles. Ind. Health 2005, 43, 403-412.

16. Mechanical Vibration and Shock-Evaluation of Human Exposure to Whole-Body Vibration-Part 5: Method for Evaluation of Vibration Containing Multiple Shocks (ISO 2631-5); International Organization for Standardization (ISO): Geneva, Switzerland, 2004.

17. Wikström, B.O. Effects from twisted postures and whole-body vibration during driving. Int. J. Ind. Ergon. 1993, 12, 61-75.

18. Eger, T.; Stevenson, J.; Callaghan, J.P.; Grenier, S.; VibRG (Vibration Research Group). Predictions of health risks associated with the operation of load-haul-dump mining vehicles: Part 2-Evaluation of operator driving postures and associated postural loading. Int. J. Ind. Ergon. 2008, 38, 801-815.

19. Eger, T.; Stevenson, J.; Grenier, S.; Boileau, P.E.; Smets, M. Influence of vehicle size, haulage capacity and ride control on vibration exposure and predicted health risks for LHD vehicle operators. J. Low Freq. Noise V. A. 2011, 30, 45-62.

20. Ozkaya, N.; Willems, B.; Goldsheyder, D. Whole-body vibration exposure: A comprehensive field study. Am. Ind. Hyg. Assoc. J. 1994, 55, 1164-1171.

21. Waters, T.; Rauche, C.; Genaidy, A.; Rashed, T. A new framework for evaluating potential risk of back disorders due to whole body vibration and repeated mechanical shock. Ergonomics 2007, 50, 379-395.

22. Johanning, E.; Fischer, S.; Christ, E.; Gores, B.; Luhrman, R. Railroad Locomotive Whole-Body Vibration Study: Vibration, Shocks and Seat Ergonomics. In Proceedings of the First American Conference on Human Vibration, Morgantown, WV, USA, 5-7 June 2006.

23. Cooperrider, N.; Gordon, J. Shock and Impact on North American Locomotives Evaluated with ISO 2631 Parts 1 and 5. In Proceedings of the First American Conference on Human Vibration, Morgantown, WV, USA, 5-7 June 2006.

24. Eklund, J.; Odenrick, P.; Zettergren, S. Head posture measurements among work vehicle drivers and implications for work and workplace design. Ergonomics 1994, 37, 623-639.

25. Krause, N.; Ragland, D.; Greiner, B.; Fisher, J.; Holman, B.; Selvin, S. Physical workload and ergonomic factors associated with prevalence of back and neck pain in urban transit operators. Spine 1997, 22, 2117-2126.

26. Bovenzi, M.; Betta, A. Low-back disorders in agricultural tractor drivers exposed to whole-body vibration and postural stress. Appl. Ergon. 1994, 25, 231-241. 
27. Nishiyama, K.; Taoda, K.; Kitahara, T. A decade of improvement in whole-body vibration and low back pain for freight container tractor drivers. J. Sound Vib. 1998, 215, 635-642.

28. Cann, A.; Salmoni, A.; Eger, T. Predictors of whole body vibration exposure in transport truck operators. Ergonomics 2004, 47, 1432-1453.

29. Eger, T.; Contratto, M.; Dickey, J.P. Influence of driving speed, terrain, seat performance and ride control on predicted health risk based on ISO 2631-1 and EU Directive 2002/44/EC. J. Low Freq. Noise V. A. 2011, 30, 291-312.

30. Bovenzi, M. Low back pain disorders and exposure to whole-body vibration in the workplace. Semin. Perinatol. 1996, 20, 38-53.

31. Reid-Bush, T.; Hubbard, R. Biomechanical Design and Evaluation of Truck Seats; SAE Paper: 2000-01-3406; ARRB Group Limited: Victoria, Australia, 2000; pp. 37-43.

32. Boileau, P.E.; Boutin, J.; Eger, T.; Smets, M.; VibRG (Vibration Research Group). Vibration Spectral Class Characterization of Load-Haul-Dump Mining Vehicles and Seat Performance Evaluation. In Proceedings of the First American Conference on Human Vibration, Morgantown, WV, USA, 5-7 June 2006.

33. Godwin, A.; Eger, T. Using virtual computer analysis to evaluate the potential use of a camera intervention on industrial machines with line-of-sight impairments. Int. J. Ind. Ergon. 2009, 29, 146-151.

34. Godwin, A.; Eger, T.; Salmoni, A.; Dunn, P.G. Virtual design modifications yield line-of-sight and safety related improvements for load-haul-dump operators, Int. J. Ind. Ergon. 2008, 38, 202-210.

35. Griffin, M.J. Minimum health and safety requirements for workers exposed to hand-transmitted vibration and whole-body vibration in the European Union: a review. Occup. Environ. Med. 2004, 61, 387-397.

36. Lings, S.; Leboeuf-Yde, C. Whole-body vibration and low back pain: A systematic, critical review of the epidemiological literature 1992-1999. Int. Arch. Occup. Environ. Health 2000, 73, 290-297.

37. Bovenzi, M.; Hulshof, T.J. An updated review of epidemiologic studies on the relationship between exposure to whole-body vibration and low back pain (1986-1997). Int. Arch. Occup. Environ. Health 1999, 72, 351-365.

38. The European Parliament and the Council of the European Union. Directive 2002/44/EC of the European parliament and of the Council of 25 June 2002 on the minimum health and safety requirements regarding the exposure of workers to the risks arising from physical agents (vibration) (16th individual Directive within the meaning of Article 16(1) of Directive 89/391/EEC). Official Journal of the European Communities, 6 July 2002.

(C) 2013 by the authors; licensee MDPI, Basel, Switzerland. This article is an open access article distributed under the terms and conditions of the Creative Commons Attribution license (http://creativecommons.org/licenses/by/3.0/). 